\title{
TRADISI PEMBERIAN KANAAN DAN PEMILIHAN DALAM KEPERCAYAAN ISRAEL
}

\section{Robi Prianto}

\begin{abstract}
Tradition of awarding Canaan and elections in Israel confidence occur simultaneously. When the Israelites were brought out of the land of Egypt to the land of Canaan, at that time the people of Israel was born into humanity of God. Canaan for the Israelites is a testament to the inclusion and the presence of a God over them, so no matter the people of Israel kept the land claim and maintain Canaan as their inheritance.Therefore Israelities were failed to become humanity of God, so is God to give status humanity of God to every body without to seeing is ethnic nation, provided they to belive to Jesus Christ as God and savior.
\end{abstract}

Key Words: Tradition, awarding, elections, confidence of Israel, and savior.

\section{PENDAHULUAN}

Status kepemilikan tanah Kanaan sejak zaman Israel kuno selalu berganti-ganti, karena tanah Kanaan sering kali dikuasai dan diperebutkan oleh banyak bangsa. Hal itu terjadi karena lokasi tanah Kanaan yang subur dan strategis di daerah Timur Tengah. Selain itu adanya nilai historis dan keyakinan yang kuat di dalam diri bangsa-bangsa yang pernah menguasainya, sehingga menimbulkan konflik yang berkepanjangan dan menyebabkan banyak korban jiwa yang berjatuhan. Bahkan berulang kali Yerusalem yang menjadi pusat kegiatan di dalam kepercayaan Israel, hancur porak poranda karena peperangan yang 
terjadi di antara bangsa-bangsa yang memertahankan dan memerebutkannya.

Dewasa ini, tanah Kanaan yang ada di Palestina (Timur Tengah) menjadi perebutan antara Negara Israel dan Palestina, kedua negara mengklaim bahwa tanah itu merupakan milik mereka. Masing-masing tidak ada yang mau mengalah, sehingga terjadi pertumpahan darah di antara kedua negara tersebut yang merenggut banyak korban jiwa. Selain itu, Yerusalem bahkan menjadi tempat suci dari tiga agama besar yang ada di dunia ini (Yahudi, Islam dan Kristen). Permasalahan yang terjadi di Palestina merupakan masalah yang rumit, dan kompleks sehingga tidak mudah untuk diselesaikan, karena masing-masing kelompok bertahan pada pandangannya sendiri. Bahkan permasalahan atau konflik yang terjadi di Palestina terus menjadi topik yang panas dan sensitif dibeberapa negara.

Bertolak dari Tradisi Pemberian Kanaan dan Pemilihan dalam kepercayaan Israel, maka ada beberapa pertanyaan penting dalam kaitannya dengan kehidupan orang percaya. Pertama, bagaimanakah peranan tanah Kanaan bagi umat Israel? Kedua, apakah makna pemberian Kanaan dan Pemilihan bagi umat Israel? Ketiga, adakah korelasi antara pemberian Kanaan dan pemilihan dalam kepercayaan Israel dengan kehidupan orang percaya?

Melalui tulisan ini, pertama-tama dijelaskan mengenai peranan tanah Kanaan bagi umat Israel. Kedua, menjelaskan tentang makna pemberian Kanaan dan pemilihan bagi umat Israel. Ketiga, memaparkan tentang korelasi antara pemberian dan pemilihan Allah terhadap Israel dengan kehidupan orang percaya.

\section{Tradisi Pemberian Kanaan dan Pemilihan dalam Kepercayaan Israel}

Kata 'tradisi' menurut Kamus Besar Bahasa Indonesia memiliki arti: suatu adat kebiasaan yang dilakukan turun-temurun (dari nenek moyang) yang masih dijalankan dalam masyarakat di setiap tempat atau suku-suku 
berbeda. ${ }^{1}$ Kata 'pemberian' berarti “sesuatu yang diberikan; hadiah, anugerah, karunia", sedangkan kata 'pemilihan' berarti "hal, cara, hasil, atau proses kerja memilih." 3 Jadi tradisi pemberian Kanaan dan pemilihan berarti suatu kebiasaan yang terus dipegang dan diyakini oleh bangsa Israel secara turun-temurun mengenai pemilihan yang dilakukan oleh Allah kepada bangsa Israel sebagai umat pilihan Allah, dan pemberian tanah Kanaan sebagai milik kepunyaan mereka. Semuanya itu diberikan oleh Allah secara cuma-cuma sebagai suatu anugerah melalui suatu proses yang panjang.

Tanah Kanaan berada di lokasi yang strategis di antara peradabanperadaban besar di Timur Dekat. Di sebelah Barat Kanaan berbatasan dengan Mesir. Di sebelah Utara berbatasan dengan Fenisia, dan Aram (Siria). Di sebelah Timur berbatasan dengan Asyur dan Babilonia. Keadaan yang demikian, telah menjadikan Kanaan sebagai tempat yang banyak dilalui dan disinggahi banyak bangsa, sehingga ketika terjadi peperangan negeri Kanaan tidak pernah aman. Sebab Kanaan dijadikan sebagai jembatan atau perantara untuk menaklukan daerah-daerah Timur Dekat. ${ }^{4}$

Bentuk kepercayaan dari orang-orang Kanaan adalah Politeisme yaitu, menyembah banyak dewa. Orang-orang Kanaan memahami dan memercayai bahwa kekuasaan para dewa tidaklah mutlak, di mana di setiap tempat ada dewa penguasanya, dewa sesembahan yang paling utama bagi orang-orang Kanaan adalah Baal. Orang-orang Kanaan memercayai, bahwa Baal akan melindungi dan memberi kesejahteraan hidup bagi mereka, sehingga tidak heran Baal oleh orang Kanaan diwujudkan dalam berbagai bentuk seperti dewa cuaca, dewa perang, atau pun dewa kesuburan. Ketergantungan orang-orang Kanaan

1J.S. Badudu \& Sutan M. Zain, Kamus Umum Bahasa Indonesia (Jakarta: Pustaka Sinar Harapan, 1996), 1531.

2 Ibid, 169.

3 Ibid, 1062

${ }^{4}$ J.I. Packer, Merrill C. Tenney, \& William White, Jr, Ensiklopedia Fakta Alkitab, Vol.1 (Malang: Gandum Mas, 2003), 353. 
terhadap Baal sangat tinggi, hal itu dapat terlihat dari banyaknya patungpatung Baal yang mendominasi di dalam kuil-kuil orang Kanaan. Baal akan melindungi dan memberikan kesejahteraan kepada mereka, jika mereka menjaga keseimbangan atau kestabilan hukum-hukum yang ada.

Ketika orang-orang Israel menaklukkan dan menguasai Kanaan, maka kepercayaan terhadap Politeisme digantikan dengan Monoteisme, di mana hanya satu Allah yang disembah yaitu Yahwe. Umat Israel memercayai bahwa Allah itu tidak dibatasi oleh tempat dan waktu, karena Allah bekerja dalam aktivitas dan misteri alam, serta memahami bahwa Allah juga berada tinggi di atas dan jauh melampaui alam. ${ }^{5}$ Proses penaklukkan tersebut berlangsung cukup lama, dan di dalam prosesnya tidak semua tanah Kanaan dikuasai oleh umat Israel.

\section{Peranan Tanah Kanaan Bagi Israel}

\section{Milik Umat Allah}

Umat Israel menyakini bahwa tanah Kanaan merupakan milik mereka yang diberikan oleh Allah. Nabi Yeremia menggambarkan Kanaan itu sebagai tanah yang permai (Yer 3:19). Pandangan umat Israel tentang tanah Kanaan sebagai milik pribadi mereka, merupakan pandangan yang keliru, karena sebenarnya Allah memberikan tanah kanaan kepada umat Israel sebagai tempat kediaman bukan milik pribadi. Bahasa Ibrani yang dipakai untuk menunjuk kepada milik pusaka adalah nahalah, namun sebenarnya kurang tepat jika nahalah diartikan sebagai milik pusaka, yang lebih tepatnya adalah diartikan sebagai tempat kediaman(Yos 22:4; Hak 7:8; 1 Sam 13:2). ${ }^{6}$ Selain itu ada juga kata-kata lain yang digunakan seperti, 'ahuzzah, morasyah dan helek yang semua artinya menunjuk kepada tempat kediaman.

Jadi, pandangan mengenai tanah Kanaan sebagai milik pusaka umat Israel itu merupakan suatu pandangan yang kurang tepat. Sebab jika

${ }^{5}$ Handbook to the Bible (Bandung: Kalam Hidup, 2002), 14-15.

6 Christoph Barth, Theologia Perjanjian Lama 2 Jakarta: BPK. Gunung Mulia, 2001), 29. 
demikian, maka rencana Allah atas umat Israel terhenti atau sudah berakhir pada saat pemberian tanah itu berlangsung. ${ }^{7}$

\section{Tanah Milik Allah}

Berdasarkan tradisi dari Nyanyian Laut Teberau (Kel 15:1-18), bukit Sion di tanah Kanaan sering kali disebut sebagai gunung tempat kediaman Allah. Tradisi tersebut sangat dijunjung tinggi oleh umat Israel, bahkan hingga saat ini. Di dalam kitab Mazmur juga ada beberapa bagian yang menyebutkan Sion sebagai gunung Allah. ${ }^{8}$

Umat Israel memercayai dan meyakini bahwa tanah Kanaan adalah milik Allah, hal tersebut didasarkan pada peranan Allah yang menciptakan langit dan bumi beserta dengan segala isinya, sehingga tanah Kanaan yang merupakan bagian dari alam semesta ini merupakan milik Allah juga. Bagi umat Israel penyataan Allah melalui firman-Nya di tanah Kanaan merupakan bukti kehadiran-Nya dan kepemilikan-Nya atas tanah tersebut. Beberapa penyataan Allah di tanah Kanaan yang dijadikan dasar oleh umat Israel sebagai bentuk kepemilikan atas tanah tersebut yaitu, Allah menjanjikan kepada para bapa leluhur untuk memberikan tanah Kanaan kepada mereka, dan tanah Kanaan dijadikan tempat penyataan Allah kepada mereka (Kej 12 - 15; 26; 28; 35). Seterusnya cerita-cerita dalam kitab Yosua yang membesarkan peranan tabut perjanjian, ketika umat Israel sedang menyeberangi sungai Yordan, kemudian masuk ke Kanaan. Sebab pada awalnya tabut perjanjian berfungsi sebagai simbol kehadiran Allah, sehingga pendudukan mereka atas tanah Kanaan bisa berhasil karena adanya kehadiran Allah. Lalu ada penyataan Allah secara langsung yang menegaskan bahwa tanah Kanaan adalah milik-Nya (Im 25:23). ${ }^{9}$

7 Ibid, 31.

8 Ibid, 32.

${ }^{9}$ Ibid, 35. 
Kitab Yosua menceritakan, bahwa Israel merupakan benih (keturunan) yang dijanjikan kepada Abraham. Ketika mereka mulai melakukan penaklukkan atas Kanaan, jumlah umat Israel semakin bertambah banyak, sebagaimana janji Allah kepada Abraham, dan mereka mulai menetap di Kanaan, dengan membagi-bagi tanah itu terlebih dahulu seperti yang Allah perintahkan kepada mereka. Dalam Kejadian 49:10, dikatakan mengenai keturunan Abraham yang akan memerintah umat Israel berasal dari keturunan Yehuda. Keturunan itu, akan menjadi alat Allah untuk mengokohkan kenyataan bahwa Kanaan itu sebagai milik Israel dan akan mendatangkan berbagai berkat bagi umat Israel dan bagi dunia. ${ }^{10}$

Jadi, tanah Kanaan telah dipilih oleh Allah secara khusus untuk menjadi milik-Nya, menjadi tempat kediaman dan tempat kegiatan di tengah-tengah umat Israel. Hal itu berlaku juga terhadap umat Israel yang mendiami tanah tersebut.

\section{Tanah yang Dijanjikan}

Tanah Kanaan dalam pandangan umat Israel merupakan pemberian dari janji Allah kepada mereka. Janji tentang pemberian tanah Kanaan merupakan tema yang sangat menggema di dalam Perjanjian Lama. Alasannya adalah janji itu, sering kali diucapkan berulang-ulang oleh Allah kepada para bapa leluhur (Kej. 17:7-8; Kel. 6:7). Janji yang diucapkan oleh Allah tidak sama dengan janji yang diucapkan oleh manusia, karena terkadang manusia sering kali berjanji tetapi tidak menepatinya, berbeda dengan janji yang diucapkan oleh Allah yang tidak mungkin diingkari atau diubah-Nya. Ketika Allah menjanjikan tanah Kanaan kepada umat Israel, pada saat itu juga tanah Kanaan sudah diberikan, meskipun belum berwujud nyata dalam pandangan manusia.

${ }^{10}$ Roy B. Zuck (Ed), A Biblical Theology of The Old Testament (Malang: Gandum Mas, 2005), 190. 
Janji Allah mengenai tanah Kanaan tidak hanya untuk masa lalu saja, melainkan sampai sekarang pun janji tersebut masih berlaku. Umat Israel diberkati oleh janji tersebut, mendapatkan keyakinan dan pengharapan yang baru. Bukan hanya umat Israel yang diberkati, melainkan tanah itu sendiri pun mendapatkan berkat Allah. Janji Allah yang membuat tanah Kanaan menjadi sesuatu yang melebihi keadaan alamiahnya. Tanah Kanaan berubah wajahnya, sehingga menjadi Kanaan yang baru, di mana kasih dan kesetiaan bertemu, keadilan dan damai sejahtera bercium-ciuman (Mzm. 85:11), sehingga umat Israel menggambarkan tanah Kanaan itu sebagai negeri yang berlimpah dengan susu dan madu (Kel. 3:8). ${ }^{11}$

Jadi, Allah menjadikan tanah Kanaan sebagai pusat dan pangkalan utama dari rencana-Nya dalam mendatangkan kerajaan-Nya di bumi ini. Umat Israel diberikan tanah Kanaan oleh Allah dengan tujuan supaya mereka ambil bagian di dalam rencana Allah ini yaitu, melalui ibadah, persekutuan dan kesaksian hidup mereka. Allah memakai pembuangan sebagai instrumen pengutusan dan pemberkatan, supaya umat Israel bisa menjadi saksi sampai ke ujung bumi, di tengah-tengah segala kaum dan bangsa.

Dengan status tanah Kanaan yang adalah milik umat Allah, tanah milik Allah dan tanah yang dijanjikan, maka sangat penting bagi orangorang Israel untuk memertahankan Kanaan sebagai milik pusakanya dan sebagai tempat kelahiran mereka. Konsep ini terus dipegang dan dituruntemurunkan dari satu generasi ke generasi yang lainnya. Hal tersebut sangat memengaruhi kehidupan bangsa Israel dalam menilai tanah kelahiran mereka. Ketika terjadi peperangan di daerah Palestina, bangsa Israel dengan sekuat tenaga bahkan mereka rela mengorbankan dirinya sampai tetes darah penghabisan, berjuang demi memertahankan tanah Kanaan dari pihak luar. Sebab tanah Kanaan itu merupakan pemberian dari Allah dan secara religi tanah Kanaan adalah tanah yang kudus dan

11 Ibid, 40. 
suci. Jadi, setiap orang dari bangsa Israel dituntut untuk memertahankan tanah tersebut dari serangan musuh-musuhnya, meskipun harus melakukan peperangan. Sebab bagi orang Israel hal itu dianggap sebagai perang suci, karena mereka membela dan memertahankan kekudusan dan kesucian tanah pemberian Allah itu dari pihak asing.

\section{Makna Pemberian Kanaan dan Pemilihan bagi Umat Israel}

\section{Penggenapan Janji Allah kepada Para Bapa Leluhur}

Sejak semula Allah telah memberikan tanah Kanaan kepada para bapa leluhur Israel. Pertama kali Allah menjanjikan pemberian tanah Kanaan kepada Abraham, lalu dilanjutkan kepada Ishak dan Yakub (Kej 26:3-4; 28:3-4; 13-15). Ketika Allah memanggil Abraham dari tempat asalnya Ur-Kasdim, Allah berjanji akan menjadikan keturunannya menjadi bangsa yang besar. ${ }^{12}$

Allah menyatakan kepada para bapa leluhur untuk memberikan Kanaan kepada mereka dan keturunannya. Abraham sebagai penerima janji yang pertama dari Allah itu, meresponsnya dengan positif yaitu dengan mengambil langkah meninggalkan tempat kelahirannya. Tindakan Abraham itu merupakan suatu hal yang tidak masuk akal bagi kebanyakan orang, karena daerah asal Abraham merupakan daerah yang maju dan makmur pada masa itu. Abraham tidak memertanyakan perintah Allah yang menyuruhnya untuk pergi dari negerinya dan dari sanak saudaranya, lalu masuk ke suatu negeri asing yang akan Allah berikan kepadanya (Kej 12:1). ${ }^{13}$ Abraham menaati perintah Allah itu dan menerima janji Allah dengan sepenuh hatinya, sehingga Abraham dikatakan sebagai Bapa orang beriman.

12 Christoph Barth \& Marie-Claire Barth-Frommel, Theologia Perjanjian Lama 1, edisi revisi (Jakarta: BPK. Gunung Mulia, 2010),106.

13 J.I. Packer, Merrill C. Tenney, \&William White, Jr, Ensiklopedia Fakta Alkitab, Vol.1 (Malang: Gandum Mas, 2003), 355. 
Semasa hidupnya Abraham harus terus mengembara sebagai orang asing di negeri orang. Abraham hanya memiliki goa Makhpela yang menjadi tempat pemakaman bagi dirinya dan Sara. Janji Allah belum menjadi kenyataan bagi Abraham menurut pandangan manusia. Abraham harus menunggu dengan sabar akan janji yang Allah ucapkan kepada dirinya. Janji Allah kembali diulangi kepada Abraham dan Sara ketika mereka sudah memasuki usia tua, di mana Allah menjanjikan kepada keturunannya seluruh tanah Kanaan. Secara manusia hal itu tidak mungkin terjadi, bahkan Sara menertawakan janji Allah itu. Namun, Allah menegaskan bahwa seluruh tanah Kanaan yang dilihat oleh Abraham mulai dari sebelah Timur, Barat, Utara dan Selatan akan diberikan kepada keturunannya (Kej 13:14-15). Janji Allah mulai Abraham rasakan secara nyata, tatkala Allah mengaruniakan seorang anak kepada Abraham dan Sara di masa tuanya. ${ }^{14}$

Ketika Allah membuat perjanjian dengan Abraham untuk menjadikan keturunannya seperti pasir di laut dan bintang di langit, Allah tidak menentukan kapan batas waktu penggenapan dari janji tersebut. Umat Israel sebagai keturunan dari Abraham terhisab ke dalam perjanjian yang Allah buat kepada para bapa leluhur mereka. Umat Israel meneguhkan eksistensi kebangsaan mereka, ketika umat itu melakukan penaklukkan terhadap Kanaan. Hal itu terjadi sebagai bagian dari respons umat Israel terhadap penggenapan Janji Allah. Penggenapan janji Allah belum berakhir tatkala mereka memasuki dan menguasai Kanaan, tetapi Allah menjadikan hubungan antara diri-Nya dengan umat Israel sebagai suatu gambaran atau contoh bagi umat manusia secara keseluruhan, bahwa Allah mengasihi makhluk ciptaan-Nya. Janji Allah baru akan berakhir, ketika kerajaan Allah di bumi sudah tercipta seperti yang digambarkan di dalam kitab Wahyu (Why 21:1-22:5). ${ }^{15}$

${ }_{14}$ Barth, Theologia ..., 106.

15 Zuck (Ed), A Biblical ..., 188-189. 
Jadi, janji Allah kepada Abraham untuk menjadikan keturunannya menjadi bangsa yang besar dan memberikan tanah Kanaan sebagai tempat kediaman mereka, bukanlah sesuatu yang instan, namun memerlukan proses yang lama dan panjang dari pihak Abraham sebagai penerima janji tersebut. Akan tetapi yang perlu dipahami adalah janji Allah itu tidak terbatas pada pemberian Kanaan secara harfiah saja. Namun janji Allah itu terutama menyangkut hal keselamatan, yang berlaku tidak hanya untuk umat Israel secara lahiriah, tetapi Israel rohani juga menerima janji Allah itu, yaitu mendapatkan tempat di dalam langit dan bumi yang baru.

\section{Israel menjadi Umat Allah}

Umat Isarel sudah menjadi umat Allah pada saat Allah membebaskan mereka dari perbudakan di Mesir. Berkat tindakan Allah yang berkuasa, umat Isarel menjadi bangsa yang merdeka, suatu persekutuan yang terdiri dari orang-orang yang merdeka. Perbuatan Allah yang telah membebaskan umat Israel dari perbudakan merupakan penyebab dari kelahiran Israel sebagai umat Allah. Allah telah membebaskan Israel dari rasa takut terhadap manusia menjadi percaya atau takut kepada Allah.

Perbuatan Allah tidak hanya menyangkut umat Israel sebagai keseluruhan, tidak hanya menuntut dan membangkitkan kepercayaan kepada Allah yang membebaskan secara keseluruhan. Akan tetapi Allah menciptakan persekutuan umat Israel sebagai orang-orang merdeka. Terhadap persekutuan ini, dituntut dan dibangkitkan-Nya pengakuan. Umat Allah bersifat persekutuan dan persaudaraan dan pengakuannya terhadap kemerdekaan tiap-tiap anggotanya menjadi salah satu tanda kehidupan umat Israel, dengan mengakui kemerdekaan semua anggotanya, Isarel menjadi merdeka dengan sesungguhnya, dengan demikian mereka lahir sebagai umat Allah. ${ }^{16}$

${ }^{16}$ Barth, 135-136. 
Ketika umat Israel menjadi umat Allah, hal itu berarti mereka mengabdi dan melayani sebagai hamba Allah. Tujuan Allah membebaskan mereka dari perbudakan di Mesir adalah supaya umat Israel dapat beribadah kepada Allah tanpa adanya halangan dan Allah tidak mau umat-Nya menjadi milik pihak lain. Umat Israel diperintahkan oleh Allah untuk beribadah hanya kepada Allah saja, karena Allah sudah membebaskan, menyelamatkan, menebus mereka. ${ }^{17}$

Allah menghendaki umat Israel menjadi suatu bangsa yang berbeda dengan bangsa-bangsa di sekitarnya. Umat Israel diharapkan untuk menunjukkan iman mereka kepada Allah dengan ketaatan yang penuh rasa syukur, dan Allah menjanjikan kepada umat Israel bahwa kepatuhan kepada hukum-hukum Allah akan menjamin keberhasilan mereka (Ul 6:3). Allah telah memilih umat Israel untuk menjadi saksi-Nya dan melalui mereka banyak bangsa akan diberkati. ${ }^{18}$

Jika dilihat dari sudut pandang manusia yang berdosa, tindakan Allah seakan-akan sangat kejam dengan perbuatan-Nya yang memberikan tanah Kanaan kepada umat Israel, kemudian Allah memerintahkan untuk memusnahkan orang-orang yang tinggal di dalamnya. Perbuatan Allah itu seolah-olah tidak memiliki kasih kepada manusia yang lain. Namun, hal itu tidaklah benar karena Allah telah memberikan kesempatan kepada orang-orang Kanaan untuk bertobat tetapi mereka tidak mau, bahkan kejahatan mereka semakin menjadi (Kej. 15:16). Umat Israel pun harus menunggu lama untuk menerima janji Allah itu, bahkan mereka harus menjadi bangsa yang dijajah oleh bangsa lain selama kurang lebih 400 tahun (Kej. 15:13), dan mereka menjadi pengembara selama 40 tahun lamanya untuk bisa masuk ke dalam tanah Kanaan.

${ }^{17} \mathrm{Ibid}, 142$.

18 Packer, Ensiklopedia Fakta Alkitab, Vol.1, 359. 
Perbuatan Allah itu bukan tanpa sebab yang jelas, tetapi ada tujuannya. Allah memberikan kesempatan kepada orang-orang Kanaan untuk menyadari kesalahan mereka dan di sisi yang lain hal itu bertujuan untuk memurnikan iman umat Israel sebagai umat pilihan-Nya. Umat Israel sebagai umat pilihan Allah, ketika mereka memasuki tanah Kanaan secara tidak langsung mereka pasti melihat dan bersentuhan dengan kebudayaan, serta adat istiadat orang-orang Kanaan yang sudah ada sebelumnya. Hal itu sedikit banyak bisa memengaruhi iman umat Israel yang masih labil, sehingga mereka bisa terbawa menyimpang kepada penyembahaan terhadap para dewa (Baal) yang dipercayai oleh orang Kanaan. Oleh karena itu, Allah tidak mau hal tersebut sampai terjadi karena Allah menginginkan umat Israel bisa tampil beda di dalam sikap kehidupan mereka sehari-hari sebagai umat Allah. Selain itu, karena kejahatan orang-orang Kanaan sudah sangat besar, maka Allah memakai umat Israel sebagai instrumen-Nya untuk menghukum mereka dengan memberikan perintah untuk memusnahkan orang-orang Kanaan (Yos 6:17). Allah ingin menjadikan Kanaan lama menjadi Kanaan baru dengan umat pilihan-Nya yang sudah dimurnikan yang diharapkan selalu memuji dan menyembah nama-Nya, sehingga dapat menjadi contoh bagi bangsabangsa lainnya.

Jadi, identitas Israel sebagai umat Allah menjadikan mereka lain dari bangsa-bangsa di sekitarnya. Status khusus mereka sebagai umat Allah terus diturunkan dari satu generasi ke generasi berikutnya. Status Israel sebagai umat Allah telah menjadikan mereka eksklusif, sehingga mereka menganggap rendah bangsa-bangsa lainnya. Padahal Allah menjadikan mereka umat-Nya dengan tujuan supaya umat Israel dapat menyalurkan berkat Allah kepada bangsa lain, melalui ibadah, persekutuan dan kesaksian hidup sebagai umat pilihan-Nya. Tugas yang diemban oleh umat Israel sebenarnya sangat berat, karena Allah menuntut ketaatan mutlak dari mereka sebagai umat pilihan-Nya. Dalam kenyataannya, umat Israel telah gagal dalam tugas yang diberikan oleh Allah itu. Umat 
Israel lebih sibuk mengurus diri mereka sendiri dan bersikap pasif dalam rencana besar Allah untuk mendatangkan kerajaan damai di dunia ini.

\section{Korelasi dengan Kehidupan Orang Percaya Masa Kini}

Pemilihan umat Israel sebagai umat Allah tidak terbatas pada pemberian tanah perjanjian atau Kanaan saja, tetapi menyangkut juga akan hal keselamatan. Perbuatan Allah yang ajaib itu dapat terlihat dari medan sejarah umat Israel, di mana perbutan Allah yang terus menerus menyertai umat Israel. Rentetan perbuatan Allah yang ajaib itu terpapar dengan jelas di dalam Perjanjian Lama, tetapi rentetan itu terkadang tidak berurut atau bersambung, karena ketika Allah membuat janji, maka saat itu juga Allah menggenapinya. Akan tetapi rentetan perbuatan Allah itu bisa dilihat dari peristiwa penciptaan dunia, dilanjutkan dengan pemilihan para bapa leluhur (Kel. 2:24; Im. 26:42), kemudian adanya peristiwa keluaran di Mesir (Ams. 3:1; Hos. 11:1), lalu perjalanan di padang gurun (Ul. 32:10; Yer 3:2), kemudian penyataan Allah di gunung Sinai (Mzm. 50:81), dilanjutkan dengan pemberian tanah Kanaan (Yes. 5:1-7), disambung dengan pemilihan Sion atau Daud (Mzm. 89). ${ }^{19}$

Allah menginginkan ketaatan yang mutlak dari umat Israel sebagai umat pilihan-Nya. Allah memilih Israel untuk menjadi umat-Nya dengan tujuan supaya mereka dapat menjadi sarana bagi perpanjangan tangan Allah dalam memberkati bangsa-bangsa lain. Namun, umat Israel telah gagal di dalam tugas mereka sebagai umat Allah. Berulang kali Alkitab mencatat, jika umat Israel selalu mendukakan hati Allah, bahkan mereka sering kali menyimpang dari Allah. Ketika, umat Israel menyimpang dari Allah, maka mereka pun mendapatkan hukuman dari Allah. Terakhir Alkitab mencatat, bahkan sejarah dunia pun menyaksikan, bagaimana Allah menghukum umat Israel ke dalam pembuangan negeri asing, terpisah jauh dari tanah kelahirannya. Hukuman Allah itu bertujuan supaya mereka menyadari kesalahannya kemudian bertobat kembali kepada Allah. Hal tersebut menunjukkan bahwa Allah itu maha kasih

${ }^{19}$ Barth, ..., 23. 
terhadap umat-Nya. Dampak dari kegagalan Israel sebagai umat pilihanNya, yaitu berkat keselamatan tidak lagi hanya milik bangsa Israel, namun Allah membagikannya juga kepada bangsa-bangsa lain.

Satu pertanyaan timbul dari kegagalan bangsa Israel di dalam menjalankan tugasnya sebagai umat Allah adalah apakah Israel tetap menjadi bangsa pilihan Allah dan apakah janji Allah atas mereka dibatalkan? Jawaban dari pertanyaan tersebut yaitu, bahwa Allah tidak pernah membatalkan perkataan-Nya karena sifat Allah itu adalah setia. Israel tetap menjadi umat Pilihan Allah dan berkat Allah tetap tercurah atas mereka, seperti yang dijanjikan-Nya kepada Abraham, bahwa Allah akan menjadikan keturunannya menjadi bangsa yang besar, dan melaluinya banyak bangsa akan diberkati (Kej 12:2-3). Namun, itu berkaitan dengan berkat Allah secara jasmani, sedangkan berkat keselamatan tidak lagi menjadi milik Israel sepenuhnya karena mereka telah menolak keselamatan itu sendiri yaitu dengan tidak memercayai Yesus sebagai Tuhan dan Juruselamat mereka. Akan tetapi, berkat keselamatan tetap bisa diperoleh oleh orang-orang Israel tetapi tidak lagi melalui status mereka sebagai bangsa pilihan, namun secara pribadi lepas pribadi sama seperti orang-orang yang bukan berasal dari keturunan bangsa Israel.

Perbuatan Allah yang maha kasih itu, tidak hanya berlaku bagi bangsa Israel saja, tetapi juga hal itu berlaku bagi setiap orang percaya saat ini. Sebab orang percaya juga adalah keturunan dari Abraham karena Abraham adalah bapa orang beriman. Orang percaya merupakan keturunan Abraham, tetapi bukan keturunan secara lahiriah, namun secara rohani. Di dalam 2 Korintus 5:17 mengatakan, bahwa orang yang hidup di dalam Kristus adalah ciptaan baru. Hal tersebut dimaksudkan bagi semua orang tidak terkecuali mereka yang berasal dari keturunan Israel secara lahiriah. Sebab rencana keselamatan Allah tidak terbatas hanya pada Israel secara lahiriah saja, namun bagi setiap orang yang percaya di dalam Kristus. Kristus Yesus merupakan jembatan yang menghubungkan orang percaya dengan Allah, sehingga berkat keselamatan bisa dinikamati juga oleh semua orang dari semua bangsa 
dan bahasa, asalkan percaya kepada Yesus Kristus sebagai Tuhan dan Juruselamat (Yoh. 14:6). Seperti yang Tuhan Yesus katakan bahwa Dia pergi untuk memersiapkan tempat bagi orang-orang percaya karena di rumah Bapa-Nya banyak tempat (Yoh. 14:2).

\section{Kesimpulan}

Berdasarkan pemaparan di atas tradisi pemberian tanah Kanaan dan pemilihan dalam kepercayaan Israel terjadi secara bersamaan. Ketika, umat Israel dibawa keluar dari tanah Mesir menuju tanah Kanaan, pada saat itu juga umat Israel lahir menjadi umat Allah. Status Israel sebagai umat Allah menjadikan mereka lebih dari bangsa lain, dan dengan status tersebut umat Israel seharusnya menjadi perpanjangan tangan Allah dalam menyalurkan berkat kepada bangsa-bangsa lain. Hal itu bukan berarti Allah tidak sanggup untuk secara langsung memberkati bangsabangsa lainnya, tetapi Allah menginginkan peran aktif dari umat-Nya untuk mengambil bagian dalam rencana besar-Nya atas dunia ini yaitu, mendatangkan kerajaan Allah.

Akan tetapi pada pelaksanaannya, umat Israel telah gagal di dalam menjalankan tugas yang diberikan oleh Allah kepada mereka. Umat Israel sering kali menyimpang dari Allah dan sikap kehidupan mereka sama seperti bangsa-bangsa di sekitarnya. Setiap tindakan pasti ada konsekuensinya, begitu juga dengan tindakkan umat Israel yang sering mendukakan hati Allah dan telah gagal di dalam menjalankan tugasnya, maka Allah mengambil hak istimewa keselamatan dari bangsa itu dan membagikannya kepada semua orang dari semua bangsa dan bahasa yang ada di dunia ini. 